\title{
Protection of Natural Wetlands through Landscape Design in Kigali City
}

\author{
Rahman Tafahomi* and Reihaneh Nadi \\ Department of Architecture, School of Architecture and Built Environment, College of Science and \\ Technology, University of Rwanda, Kigali, Rwanda \\ *Corresponding Author: tafahomi@gmail.com; r.tafahomi@ur.ac.rw \\ DOI: $10.4314 /$ rjeste.v4i1.11 \\ https://dx.doi.org/10.4314/rjeste.v4i1.11
}

\begin{abstract}
The city of Kigali has been experiencing rapid growth in recent years. The city enjoys a variety of natural features such as wetland, valley, hill, and great scenery, however, fast expansion of urban areas and human activities could pose a serious threat to the natural environment, and the ecological sustainability. While wetlands, as nature's kidneys, bring obvious benefits to both ecology and the socioeconomic environment, they have currently faced several problems in Kigali, such as pollution and the risk of decline in the area. This research is aimed at protection of wetland areas through landscape design, which could have a positive influence on maintaining the natural balance of ecology, as well as citizens' health and well-being. The site study was Kiyovu wetland as one of large wetlands playing a vital role in the city's character and spatial structure. The research employed observation, questionnaire, and mapping techniques, and the random sample consisted of 37 residents, workers, passers-by, and young people. Findings revealed that safety, environmental issues, accessibility, recreational activities, and quality of the wetland, were significant factors in order of priority that respondents had stressed over the design of the wetland landscape concept. The proposed concept highlighted recreation areas and the connection with other wetlands and green areas as a whole in the city, and it was derived from survey, mapping the results of questionnaires, and feedback from participants. In conclusion, Kiyovu wetland has an enormous capacity to put the idea of green magnet into effect across the city. However, the protection of wetlands without 1 . Site-specific ecological landscape plans representing strategic and design levels in periods of time, 2. Legal requirements, and 3. Public awareness about impacts of wetlands degradation would be far less effective. To set up a campaign and
\end{abstract}


a task force to examine changes can make a huge difference to levels of progress and performance.

Keywords: Ecological Landscape Design, Green Magnet, Natural Wetlands

\section{Introduction}

The city of Kigali is the capital, the largest city, and the most important business center of Rwanda. The city has been highly influenced by distinctive natural features, especially hilly landform, valleys, forests, farms, gardens, and wetlands. However, those areas are highly likely to be threatened with the destruction owing to fast development of urban areas. it is widely considered that natural wetlands as 'natural kidneys' bring many benefits such as opportunities of employment, recreation areas, appropriate farming, flood control, water filter, natural beauty, and wildlife protection (Barbier, Acreman, \& Knowler, 1997). In this way, wetland areas seem to be one of Kigali's key natural characteristics providing opportunities to make a contribution to economic growth, environmental sustainability, and connected green spaces.

The wetlands cover roughly $12.5 \%$ of Kigali's total area (REMA, Rwanda: state of environment and outlook report 2013, 2013). According to Kigali Master Plan, wetlands as the main component of Environmental Treatment Zones (ETZ's) should be protected, and so the residential areas are restricted within twenty meters of wetlands (OZ, 2007). However, it has not acted as an efficient deterrent to prevent environmental degradation resulting of industrial uses, unsuitable agricultural practices, and unplanned settlements expansion. This means that these areas are prone to incompatible activities with ecological context (Yuanjing, Binyang, \& Ashraf, 2015), which could convert the original form and character of wetlands into a fragile setting possibly becoming worse under pressure of future development.

This trend can seriously damage the environmental resources and attributes like visual and perceptual qualities of the city (Pallasmaa, 2005; Curtis, 2012). For example, rivers not only effectively protect the flora and fauna but also involve aesthetic and identity aspects of the areas (Zhao, Luo, Wang , \& Cai, 2013). The character of rivers in most wetlands of Kigali has changed to channels of the water, which are susceptible to high level of pollution, and mosquito breeding grounds. As a result, current conditions of the wetlands cannot support 
shaping green magnets, which lead, for example, to enhancing the communities' sense of place (Moughtin \& Shirley, 2006) and protection of the city's potential ecological capacities.

In recent years, many cities have improved green areas as the green magnets (Gobster, 1995) through recreational activities (Chiesura, 2004), natural, aboriginal, landscaping (Bell, 2004; Bell, 2008), cultural (Tafahomi \& Nadi, 2020), and place making process (Eroğlu, Müderrisoğlu, \& Kesim, 2012). This concept focuses specially on a link between the ecology and landscape design (Andreou, 2014). Therefore, natural wetlands have the potential to be transformed into ecological landscape projects (Turner, Gardner, \& o'Neill, 2001), using a landscape design approach that brings different parts of the city together and acts as green magnets.

It is true that the protection of wetlands has become a global matter. Studies have revealed three important issues regarding urban wetlands. Firstly, it is reported that generally over 50 $\%$ of wetlands as green areas have been gradually degraded in the world (Ramirez \& Fennell, 2014). Secondly, one of the underlying causes of this problem is the unawareness of the general public about the value of the wetlands. Thirdly, the unplanned protection could drive natural wetlands into unsustainable exploitation and spontaneous development (Wang, Yao, $\& \mathrm{Ju}, 2008)$.

\section{The Natural Wetlands in Cities}

Wetlands are of great benefit to both human and environment. These areas have an impact on production and provision of services based on hydrological, ecological, and geographical specifications, particularly in the banks of rivers and streams (Bassi, Kumar, \& Sharma, 2014). In other words, wetlands reflect the dynamic interaction between land and water (Mohamed, Othman, \& Ariffin, 2012), waterscape (Tafahomi \& Nadi, 2020), landscape (Bindera, Göttle, \& Shuhuai, 2015), and soundscape (Liu, Kang, Behm, \& Luo, 2014). Therefore, any changes in wetlands would appear to influence the quality of landscape (Chiotelli, 2015), climate, and even flora and fauna (Bond, Lake, \& Arthington, 2008). At the same time, they have a unique capacity to contribute the idea of biophilia in urban areas, which means that human beings have a tendency to closely interact with nature and other forms of life (Cabanek, Baro, \& Newman, 2020). Some studies indicated that poor quality landscape is linked to the low level of citizens' awareness of the role of landscape in urban areas (Berte, Panagopoulos , \& Zanon, 2013; Tafahomi, 2021). Thus, the developed 
landscape indicates a higher level of knowledge about the environment (Bently, Alcock, Murrian, McGlynn, \& Smith, 2003; Tafahomi, 2021), but it still faces challenges of environmental knowledge and cultural priorities in many societies (Berte, Panagopoulos, \& Zanon, 2013).

The landscape design of wetlands needs to be given more attention. The wetlands in cities could positively provide significant qualities such as pleasure, beauty, comfort through interrelation between man and nature (Muderrisoglu \& Demir, 2004). In detail, people respond to the visual and perceptual qualities such as visual corridors, local views, gates, edges, and landmarks consciously (Bently, Alcock, Murrian, McGlynn, \& Smith, 2003). Some researchers stated that well-designed and -managed urban green spaces can bring a huge improvement in the general public' health, natural habitats (M'Ikiugu, Kinoshita, \& Tashiro, 2012), well-being (Ward Thompson, 2011), and recreational activities (Malek, Mariapan, \& Shariff, 2012).

A study highlighted that the quality of wetland design shows how human used, managed, and conserved the environment (Alphan \& Derse, 2013). In other words, quality of landscaping has been interpreted as the relationship between the social and natural parameters in the specific area, meaning that communities with rich landscape, have benefited from a rich cultural framework for conserving their environment (Berte, Panagopoulos , \& Zanon, 2013; Tafahomi \& Nadi, 2020).

The current conditions of wetlands have demonstrated that main problems are rooted in urban expansion and societal point of view to agricultural activities (Alphan \& Derse, 2013). This emphasizes the importance of connection between people and environment by ecological landscape design (Andreou, 2014; Yuanjing, Binyang, \& Ashraf, 2015). Moreover, the level of the public's accessibility to recreation spaces could show both levels of integration of such activities in the local economy (Schägnera, Brander, Maes, \& Paracchini, 2016), and the general public's understanding of the benefits of ecological design of wetlands (Xu \& Wall, 2007).

The recreation areas and facilities are a key component of the wetland landscape design. A number of studies argued that the integration of the green spaces and blue spaces in a recreation area could provide an effective opportunity to improve the quality of life for 
normal people (Gigliotti, Jarrott, \& Yorgason, 2004; Tafahomi \& Nadi, 2020). The results of studies demonstrated the natural landscape influences human wellbeing in the short term and long term (Anthony \& Watkins, 2002; Bonnes \& Bonaiuto, 2002). In fact, the direct contact with green spaces, landscape, and doing gardening could improve the physical, mental, and social health of citizens (Sanders \& Stappers, 2008; Sanchez \& Liamputtong, 2017; Tafahomi \& Nadi, 2020).

In terms of landscape design process, some studies recommended participatory design as a solution to urban projects (Manzini \& Rizzo, 2011; Hussain, Sanders, \& Steinert, 2012; Iversen \& Dindler, 2014). The participatory design has been introduced to facilitate the process of bringing designers, stakeholders, and laypeople together to identify problems and solutions (Hussain, Sanders, \& Steinert, 2012). It can be classified into three stages, namely development of rudimentary design ideas, discussion about ideas with participants, and making decision collectively (Hussain S. , 2010). The purpose of the participatory design is the shift from designers, technical experts, and authority figures to stakeholders and users to provide a social production (Manzini \& Rizzo, 2011), and at the same time, it can accelerate the mutual learning among multiple participants (Iversen \& Dindler, 2014). Nevertheless, a lack of trust (Raymond, 1984) and knowledge, meaning that participants are not trained or aware of the subject area they are involve in, could affect the level of participation of ordinary people in research, to a large extent (Hillier, 2002).

\section{Research Methodology}

\subsection{Methodology}

The methodology of research focused on the qualitative methods (Miller, Dingwall, \& Morphy, 2004; Neuman, 2006) using "research through design" approach (Frayling, 1993) to interact with the contextual circumstances (Katoppo \& Sudradjat, 2015). In this regard, some relevant techniques were applied such as structured observation (Marshall \& Rossman, 2006; Tafahomi \& Nadi, 2020), semi-structured interview (Tafahomi, 2020), site analysis (White, 1983; Tafahomi, 2021), and mapping technique (Moughtin, Cuesta, Sarris, \& Laurea, 1999; Groat \& Wang, 2002; Tafahomi \& Nadi, 2020) based on participation of users (Katoppo \& Sudradjat, 2015). 


\subsection{Research Design}

In the first place, the structured observation (Miller, Dingwall, \& Morphy, 2004; Neuman, 2006) was applied to investigate environmental features and landscape elements; both green and blue spaces in the wetland (Moughtin \& Shirley, 2006; Tafahomi \& Nadi, 2020). This is followed by doing interview, which involved three fundamental questions in order (Cowan, 2001), namely "what do you like in this place? What do you dislike in this place? What do you like to be improved in this place?" These questions were aimed to identify users' needs and aspiration, and to encourage people to actively engage in process of place making. The students of the department of architecture at the University of Rwanda were trained to carry out survey and face-to-face interviews with target group. They visited the site study on weekdays and interviewed 37 visitors, inhabitants, passers-by, and workers. The output of the interview was mapped and then it was integrated with other layers of information in following stages. The site analysis was conducted using the mapping technique to produce visual, perceptual, people's desire for the wetland and surrounding areas, and potential opportunities maps. Afterwards, all layers were placed on top of one another to provide analytical map indicating the most important limits and opportunities. Finally, the primary concept of the wetland has been developed through landscape design, as well as collecting participants' feedback.

\subsection{The Site of Study}

The City of Kigali is comprised of three districts called Gasabo, Nyarugenge, and Kacyiru. The major wetland area is located near the River Nyabugogo, between the Nyarugenge and Kacyiru districts. Whereas the proportion of wetland areas in Gasabo district is around 9\%, Nyarugenge and Kacyiru districts encompasses approximately $20 \%$ of the total wetland areas (REMA, 2013; REMA, 2017). The chosen site in this research is Kiyovu wetland in Gasabo district. It is surrounded by city-scale administrative, commercial, and cultural activities, but it has been highly overused by human activities such as agriculture and industry posing threats of pollution, flooding, insecurity, and landslide. 


\section{Results}

The analysis involved four parts; the semi-structured questions, mapping, getting feedback, and concept generation. The sample was composed of 37 participants including men $(51.35 \%)$, and women $(48.65 \%)$, who were willing to participate in the interview. The percentage of residents, workers (such as farmers and vendors), passers-by, and children were $18.92 \%, 43.24 \%, 24.32 \%$, and $13.51 \%$, respectively. In fact, the randomly selected respondents were people living, working, visiting, and playing in the area. Table 1 shows the participants' attributes according to gender and their interaction with the site.

Table 1: Sample of Interviewee by Gender

\begin{tabular}{c|cccc} 
GENDER & \multicolumn{4}{c}{ PARTICIPANTS } \\
\cline { 2 - 6 } & Residents & Workers & $\begin{array}{c}\text { Passers- } \\
\text { by }\end{array}$ & Children \\
MALE & 3 & 7 & 5 & 3 \\
FEMALE & 5 & 10 & 2 & 2 \\
TOTAL & 8 & 17 & 7 & 5
\end{tabular}

Analysing the interview-based data indicated that participants highly attached importance to the agricultural products and activities (64.86\%) due to economic benefits, and then open spaces $(54.05 \%)$ and natural characteristics (45.95\%) in order of priority. From their personal perspective, major problems of the wetland were insecurity $(56.76 \%)$, non-designed areas meaning a lack of recreational activity (51.35\%), serious environmental hazards such as pollution, waste, and flooding (48.65\%), and also some residents and workers mentioned the ownership issue $(24.32 \%)$. In the question of what the respondents do want and need in the area, the majority of them strongly recommended security (78.38\%), environmental qualities pertaining to health $(64.86 \%)$, accessibility $(56.76 \%)$, recreational activities $(54.05 \%)$, and a designed form of the wetland (37.84\%).

The analysis identified that the insecurity was the most important concern for the respondents. The environmental dangers and health were highly emphasised by both residents and farmers. While accessibility was significant for both workers and passers-by, the development of recreation spaces such as parks and other types of public spaces took the 
top priority by young children. At the end, approximately $75 \%$ of respondents were willing to participate actively in a better protection of the wetland.

In the second stage, the results of interviews were converted into a cognitive map to represent the perceptual aspects of the area by some sketches, drawing, and photos. The map of desired changes and improvements in the wetland area, produced with the help of participants, called the desires map (Table 2). Additionally, all data collected was analysed through overlying and mapping techniques. In this way, outputs of observation, interview, and site analysis were overlaid in order to produce the analytical map (Table 2), which illustrated the wetland's opportunities and constraints to propose a primary landscape design concept.

The third stage started with drawing up landscape proposal in order to receive feedback from respondents. In fact, the participants developed their ideas and desire about the area, meaning that they attempted to develop and complete gradually their own perception, ideas, and knowledge over the mapping (Table 2). The research team observed a process of learning amongst the respondents about the mapping, planning, and designing. For example, respondents realised some elements of landscape design such as form, size, and density of trees, which all contribute to both conservation and security.

The last step was to conceptualise the ecological landscape of the wetland. The proposed concept involved outdoor sports, linear park, botanical garden, green path, playground, waterfront, water purification pounds. More importantly, it took the contextual aspects such as spatial structure, functionality, visual qualities, in particular green and blue areas into consideration (Table 2). 
Table 2: Mapping Process in the Research

\begin{tabular}{|c|c|c|c|}
\hline No & Title of Map & Mapping Process & Interpretations \\
\hline 1 & $\begin{array}{l}\text { Perceptual } \\
\text { Map }\end{array}$ & 1 & $\begin{array}{l}\text { Respondents indicated farmland, } \\
\text { open spaces, and some features like } \\
\text { hill, tree, and river as main } \\
\text { components of landscape. } \\
\text { The wetland acts as an edge in the city } \\
\text { based on specific form, function, and } \\
\text { limited accessibility, but people did } \\
\text { not perceive it clearly because it is } \\
\text { fragmented spatially. }\end{array}$ \\
\hline 2 & $\begin{array}{l}\text { Participants' } \\
\text { Desire Map }\end{array}$ & & $\begin{array}{l}\text { Ordinary people showed a strong } \\
\text { desire for safety, environmental and } \\
\text { health issues, removing waste, } \\
\text { improving accessibility, recreational } \\
\text { activities, like sport facility, and } \\
\text { suitable agricultural practices }\end{array}$ \\
\hline 3 & $\begin{array}{l}\text { Analytical } \\
\text { Map }\end{array}$ & & $\begin{array}{l}\text { The collected data overlaid by the } \\
\text { mapping technique to illustrate } \\
\text { opportunities and constraints of the } \\
\text { area in order that the proposed } \\
\text { ecological landscape concept could } \\
\text { be developed accordingly. }\end{array}$ \\
\hline 4 & $\begin{array}{l}\text { Opportunities } \\
\text { for Recreation } \\
\text { Spaces } \\
\text { through } \\
\text { Landscape }\end{array}$ & thes & $\begin{array}{l}\text { The map illustrated the potential } \\
\text { advantages in the area to develop } \\
\text { compatible uses, especially recreation } \\
\text { spaces with ecological context. }\end{array}$ \\
\hline 5 & $\begin{array}{l}\text { Ecological } \\
\text { Landscape } \\
\text { Concept }\end{array}$ & $y^{3}=$ & $\begin{array}{l}\text { The ecological landscape concept } \\
\text { involved both green and blue } \\
\text { (waterscape) components. It centered } \\
\text { on zoning, especially recreation } \\
\text { spaces, such as park, garden, } \\
\text { playground, field for sport, green } \\
\text { path, civic art, waterscape, and water } \\
\text { sanitation centres. }\end{array}$ \\
\hline
\end{tabular}

\section{Discussion}

Kigali master plan has not been fully implemented regarding the environmental aspects such as protection and development of wetlands, so they have faced severe challenges prevented farming in green valleys of the city (Gobster, 1995). The fact is that the policy of master plan (OZ, 2007), the development plan (CoK, 2013), and environmental considerations (REMA, 2013; REMA, 2017) has not been adequate to achieve the ecological objectives including 
ecological thought, development, and design for wetlands (Andreou, 2014; Yuanjing, Binyang , \& Ashraf, 2015). The changing process of the natural ecosystem negatively influenced the quality of landscape and climate in the city similar to consequences mentioned in some studies (Bond, Lake, \& Arthington, 2008; Bindera, Göttle, \& Shuhuai, 2015; Chiotelli, 2015; Wu \& Kil Jo, 2015).

Results of the research showed that Kiyovu wetland has the considerable potential to be designed as a green magnet through the ecological landscape. This approach could cover deficiencies of the cultural landscape literature (Berte, Panagopoulos, \& Zanon, 2013). Additionally, protection of the wetland through the ecological landscape design could support the visual quality (Bell, 2004) and recreational activities (Bell, 2008). According to results, the environmental value of Kiyovu wetland was a less important concern for people, particularly those who were gaining economic benefits, and this verified the findings of some research (Wang, Yao, \& Ju, 2008; Bassi, Kumar, \& Sharma, 2014). The wetland degradation had a negative impact on inhabitants' sense of belonging, and they did not have a clear image of the wetland's character but an unsecured, polluted, and undeveloped space, which was similar to the results of some studies (Relph, 1976; Pallasmaa, 2005; Curtis, 2012).

As numerous studies showed that the participatory approach can be helpful to collect, classify, and analyse information (Manzini \& Rizzo, 2011), similarly, this research found it useful to gather and map data like people's needs, desire, perception during the survey. However, the diversity in the provided feedback (Katoppo \& Sudradjat, 2015) challenged the accepted notion of exchange of idea (Hussain S. , 2010). In other words, co-design and co-creativity among untrained people would be effective to a certain level, so it went against the finding of a study on co-creation and landscape design (Sanders \& Stappers, 2008).

Furthermore, such a diversity among people' views over the process of design was aligned with the results of a study argued the limitation of participatory-driven research (Raymond, 1984; Hillier, 2002). As a matter of fact, respondents changed their ideas and suggestions every time as they were getting to know their living or working environment from a new perspective, which was mentioned in a number of studies (Plieninger, Dijks, Oteros-Rozas, \& Bieling, 2013). This suggested that a systematic process of training should be gone through in order to creating better opportunities for increasing awareness, promoting 
collective responsibility, and building up trust between participants, experts, and authority figures.

The wetlands design through ecological landscape approach could help with development of accessible public spaces and reconnection between people and urban environment, place identity, and place attachment. This approach stresses active protection of natural features, well-designed landscape, contextual design, and creative integration of blue and green spaces (Schägnera, Brander, Maes, \& Paracchini, 2016; Tafahomi, 2020; Tafahomi, 2021). Despite the less attention to importance of the quality of mapping and communication with respondents in participatory design literature, the results of the research revealed that people were able to better comprehend iconic and 3D maps than others, such as spatial, or analytical maps.

\section{Conclusion}

It is widely considered that wetlands have great ecological capacities and contribute to natural balance of life on earth. Their value is not restricted to natural environment, but they could support socioeconomic progress in cities. For instance, development of recreation areas in connection with wetlands by landscape design would lead to thriving economy and more public spaces for gathering and social interaction.

The landscape design is a multidisciplinary action, particularly in a wetland area with several serious concerns. This research developed an initial concept with the aim of demonstrating issues that Kiyovu wetland has been faced with, and its potential capacities as well. It appears the idea of green magnets can be put into practice, and develop recreational activities in Kigali, if properly designed and protected. To protect wetlands in Kigali, it would be necessary to provide site-specific plans for the ecological landscape design representing strategic and design level in short, medium, and long-term process. It is vital to pay attention to preparation of a clear vision, relating to protection of natural resources, and to make it a legal requirement.

In spite of the fact that restoration of wetland areas, flora and fauna, and visual aspects might be impossible, we still have time to take actions to mitigate possible dangers. For example, obtaining ecological approach to not only landscape design projects, but also other development plans and policies at a range of spatial scales would help the situation. Another 
measure that the government and city council should take is to raise public awareness about negative impacts of wetlands degradation on the natural environment, quality of life, and socioeconomic state of the city. To do this, a wetland protection campaign with diverse and creative programs could be a good idea to create a collective responsibility among resident population. Finally, to set up a task force to regularly examine, monitor, and report changes to the wetland area can make a huge difference to levels of progress and performance.

\section{References}

Alphan , H., \& Derse, A. M. (2013). Change detection in Southern Turkey using normalized difference vegetation index. Journal of Environmental Engineering and Landscape Management, 21(1), 12-18.

Andreou, E. (2014). The effect of urban layout, street geometry and orientation on shading conditions in urban canyons in the Mediterranean. Renewable Energy, 63, 587-596.

Anthony, K. H., \& Watkins, N. J. (2002). Exploring pathology: Relationships between clinical and environmental psychology. In R. Bechtel, A. Churchman, R. B. Bechtel, \& A. Churchman (Eds.), Handbook of environmental psychology (pp. 129147). New York: John Wiley \& Sons.

Barbier, E. B., Acreman, M., \& Knowler, D. (1997). Economic valuation of wetlands - A guide for policy makers and planners. Gland, Switzerland: Ramsar Convention Bureau.

Bassi, N., Kumar, D. M., \& Sharma, A. (2014). Status of wetlands in India: A review of extent, ecosystem benefits, threats and management strategies. Journal of Hydrology: Regional Studies, 2, 1-19.

Bell, S. (2004). Elements of visual design in the landscape (2th ed.). New York: Spon.

Bell, S. (2008). Desing for outdoor recreation (2nd ed.). New York: Taylor \& Francis.

Bently, I., Alcock, A., Murrian, P., McGlynn, S., \& Smith, G. (2003). Responsive environments: A manual for designers (3th Edition ed.). Oxford, UK: Architectural Press.

Berte, E., Panagopoulos , T., \& Zanon, B. (2013). An interpretative model for the management of contemporary cultural landscapes in linear infrastructure projects. Journal of Environmental Engineering and Landscape Management, 21(4), 248262.

Bindera, W., Göttle, A., \& Shuhuai, D. (2015). Ecological restoration of small water courses, experiences from Germany and from projects in Beijing. International Soil and Water Conservation Research, 3, 141-153.

Bond, N. R., Lake, P. S., \& Arthington, A. H. (2008). The impacts of drought on freshwater ecosystems: an Australian perspective. Hydrobiologia, 600, 3-16. 
Bonnes, M., \& Bonaiuto, M. (2002). Environmental psychology: From spatial-physical environment to sustainable development. In R. Bechtel, A. Churchman, R. B. BECHTEL, \& A. CHURCHMAN (Eds.), Handbook of environmental psychology (pp. 28-54). New York: John Wiley \& Sons, Inc.

Cabanek, A., Baro, M. E., \& Newman, P. (2020). Biophilic streets: a design framework for creating multiple urban benefits. Sustainable Earth, 3(7), 1-17. doi:10.1186/s42055-020-00027-0

Chiesura, A. (2004). The role of urban parks for the sustainable city. Landscape and Urban Planning, 68, 129-138.

Chiotelli, E. P. (2015). Evaluation of the effects of irrigation and drainage practices on the landscape of Lake Pamvotis, Ioannina: implications for landscape management in the context of sustainability. Agriculture and Agricultural Science Procedia, 4, 201-210.

CoK, C. (2013). City of Kigali development plan (CKDP). Kigali: City of Kigali.

Cowan, R. (2001). Placecheck: a users' guide. London: Urban Design Alliance. Retrieved from www.placecheck.com

Curtis, J. W. (2012). Integrating sketch maps with GIS to explore fear of crime in the urban environment: A review of the past and prospects for the future. Cartography and Geographical Information Science, 39(4), 175-186.

Eroğlu, E., Müderrisoğlu, H., \& Kesim, G. A. (2012). The effect of seasonal change of plants compositions on visual perception. Journal of Environmental Engineering and Landscape Management, 20(3), 196-205.

Frayling, C. (1993). Research in art and design. Royal College of Art Research Paper, 1(1), $1-5$.

Gigliotti, C. M., Jarrott, S. E., \& Yorgason, J. (2004). Effects of three types of horticultural therapy activities for persons with dementia. Harvesting Health, 3(2), 161-180.

Gobster, P. H. (1995). Perception and use of a metropolitan greenway system for recreation. Landscape and Urban Planning, 33, 401-413.

Groat, L., \& Wang, D. (2002). Architectural research methods. New York: John Willy and Sons Publisher.

Hillier, J. (2002). Shadows of power: An allegory of prudence in land-use planning. London: Routledge Press.

Hussain, S. (2010). Empowering marginalised children in developing countries through participatory design processes. CoDesign, 6(2), 99-117.

Hussain, S., Sanders, E. B., \& Steinert, M. (2012). Participatory design with marginalized people in developing countries: challenges and opportunities experienced in a field study in Cambodia. International Journal of Design, 6, 91e109. 
Iversen, O. S., \& Dindler, C. (2014). Sustaining participatory design initiatives. CoDesign, 10(3-4), 153-170.

Katoppo, M. L., \& Sudradjat, I. (2015). Combining participatory action research (PAR) and design thinking (DT) as an alternative research method in architecture. Procedia - Social and Behavioral Sciences, 184, 118 - 125.

Liu, J., Kang, J., Behm, H., \& Luo, T. (2014). Landscape spatial pattern indices and soundscape perception in a multi-functional urban area, Germany. Journal of Environmental Engineering and Landscape Management, 22(3), 208-218.

M'Ikiugu, M. M., Kinoshita, I., \& Tashiro, Y. (2012). Urban green space analysis and identification of its potential expansion areas. Procedia - Social and Behavioral Sciences, 35, $449-458$.

Malek, N. A., Mariapan, M., \& Shariff, M. K. (2012). The making of a quality neighbourhood park: A path model approach. Procedia - Social and Behavioral Sciences, 49, $202-214$.

Manzini, E., \& Rizzo, F. (2011). Small projects/large changes: Participatory design as an open participated process. CoDesign, 7(3-4), 199-215.

Marshall, C., \& Rossman, G. B. (2006). Designing qualitative research. New York: SAGE Publications.

Miller, G., Dingwall, R., \& Morphy, E. (2004). Using qualitative data and analysis. In D. Silverman, Qualitative research: Theory, method and practice (2th ed., pp. 325341). London: Sage Publications.

Mohamed, N., Othman, N., \& Ariffin, M. H. (2012). Value of nature in life: Landscape visual quality assessment at rainforest trail, Penang. Procedia - Social and Behavioral Sciences, 50, $667-674$.

Moughtin, C. J., Cuesta, R., Sarris, C., \& Laurea, P. S. (1999). Urban design: Method and techniques. London: Architecture Press.

Moughtin, C., \& Shirley, P. (2006). Urban design: Green dimensions (2 ed.). Oxford: Architectural Press.

Muderrisoglu, H., \& Demir, Z. (2004). The relationship between perceived beauty and safety in urban recreation parks. Journal of Applied Sciences, 4(1), 72-77.

Neuman, L. W. (2006). Social research methods: Qualitative and quantitative approaches (Fifth Edition ed.). Edinbourg: Pearson Education, Ink.

OZ, A. (2007). Kigali conceptual masterplan. Kigali: Ministry of Infrastructure.

Pallasmaa, J. (2005). The eyes of the skin: Architecture and the senses. Sussex, UK: John Willy \& Sons. 
Plieninger, T., Dijks, S., Oteros-Rozas, E., \& Bieling, C. (2013). Assessing mapping and quantifying cultural ecosystem services at community level. Land Use Policy, 33, 118-129.

Raymond, A. (1984). The great Arab cities in the 16th-18th centuries: An introduction. New York: New York University Press.

Relph, E. (1976). Place and placelessness. London: Pion Ink.

REMA, R. (2013). Rwanda: state of environment and outlook report 2013. Kigali: Rwanda Environment Management Authority.

REMA, R. (2017). Rwanda: state of environment and outlook report 2017. Kigali: REMA.

Sanchez, E. L., \& Liamputtong, P. (2017). Community gardening and health related benefits for a rural Victorain town. Leisure Studies, 36(2), 269-281.

Sanders, E. B.-N., \& Stappers, P. J. (2008). Co-creation and the new landscapes of design. CoDesign, 4(1), 5-18.

Schägnera, J. P., Brander, L., Maes, J., \& Paracchini, M. L. (2016). Mapping recreational visits and values of European National Parks by combining statistical modelling and unit value transfer. Journal for Nature Conservation, 31, 71-84.

Tafahomi, R. (2020). Educational outcome of students' group-table arrangement for collaboration in architectural thesis studio. LWATI: A Journal of Contemporary Research, 17(2), 22-46.

Tafahomi, R. (2021). Qualities of the green landscape in primary schools, deficiencies and opportunities for health of the pupils. J. Fundam. Appl . Sci, 13(2), 1093 -1116. doi:10.43 14/jfas.v13i2.25

Tafahomi, R., \& Nadi, R. (2020). Derivation of a design solution for the conservation of a historical Payab in the redevelopment of Doloeei, Gonabad. International Journal of Built Environment and Sustainability, 7(1), 1-9. doi:10.11113/ijbes.v7.n1.407

Tafahomi, R., \& Nadi, R. (2020). Insight into the missing aspects of therapeutic landscape in psychological centers in Kigali, Rwanda. Cities \& Health, Online, 1-13. doi:10.1080/23748834.2020.1774035

Turner, M. G., Gardner, R. H., \& o'Neill, R. V. (2001). Landscape ecology in theory and practice: Pattern and process. New York: Springer.

Wang, Y., Yao, Y., \& Ju, M. (2008). Wise use of wetlands: Current state of protection and utilization of Chinese wetlands and recommendations for improvement. Environmental Management, 41, 793-808.

Ward Thompson, C. (2011). Linking landscape and health: The recurring theme. Landscape and Urban Planning, 99(3-4), 187-195.

White, E. T. (1983). Site analysis: Diagramming information for architectural design. Tallahassee, Florida: Architectural Media Ltd. 
Wu , Q., \& Kil Jo, H. (2015). A study on ecotect application of local climate at a residential area in Chuncheon, Korea. Journal of Environmental Engineering and Landscape Management, 23(2), 94-101.

Xu , F., \& Wall, G. (2007). Ecotourism in Yancheng wetland, China. Tourism Recreation Research, 32(1), 11-19.

Yuanjing, Z., Binyang, Y., \& Ashraf, M. A. (2015). Ecological security pattern for the landscape of mesoscale and microscale land: a case study of the Harbin city center. Journal of Environmental Engineering and Landscape Management, 23(3), 192201.

Zhao, J., Luo, P., Wang, R., \& Cai, Y. (2013). Correlations between aesthetic preferences of river and landscape characters. Journal of Environmental Engineering and Landscape Management, 21(2), 123-132. 